\title{
Potential of Various Extracts of Tamarindus indica (Caesalpiniaceae) Leaves in the Treatment of Cancer
}

\author{
${ }^{1}$ V.V. Dhasade, ${ }^{1}$ S.A. Nirmal, ${ }^{2}$ S.C. Pal, ${ }^{3}$ Partha P. Maiti and ${ }^{3}$ Subhash C. Mandal \\ ${ }^{1}$ Department of Pharmacognosy, Pravara Rural College of Pharmacy, Loni, 413736, Maharashtra, India \\ ${ }^{2}$ Department of Pharmacognosy, M.V.P. College of Pharmacy, Nasik, Maharashtra, India \\ ${ }^{3}$ Pharmacognosy and Phytotherapy Research Laboratory, Department of Pharmaceutical Technology, \\ Jadavpur University, Kolkata, India
}

\begin{abstract}
Background and Objective: Globally second most frequently observed disease after heart disease is "Cancer". Despite advances in cancer treatment over the past decades, the prognosis of patients with blood cancer has improved only to small extent. Thus, there is an urgent need to develop new and effective strategies for the prevention and treatment of this form of cancer. Hence, present study was undertaken to evaluate anticancer potential of leaves of Tamarindus indica Linn. (Caesalpiniaceae). Materials and Methods: The plant leaves were collected and extracted with various solvents like petroleum ether, ethanol, ethyl acetate, chloroform and water. Various extracts of leaves were screened for anticancer activity using the methods like potato disc method, onion root-tip assay and trypan blue assay by using HL-60 Cell line in dose dependent manner. Results: Petroleum ether extract of leaves of T. indica shows more potency as compared with other extracts in the treatment of cancer in all the tests performed. Conclusion: It can be concluded that petroleum ether extract of $T$. indica leaves have potency to prevent or manage cancer cell growth.
\end{abstract}

Key words: Tamarindus indica, Caesalpiniaceae, phytochemistry, anticancer, trypan blue assay, onion root tip, potato disc assay

Insight Cancer Research 1 (1): 1-6, 2015

\section{INTRODUCTION}

Today cancer is a leading cause of death in world so it is the need of the medical science to find new drugs or to improve existing treatment for the cancer. Hence, the significance of discovering new targets, pathways and strategies for therapeutic intervention in cancer is extremely important. Ideally, chemotherapeutic drugs should specifically target only cancerous cells by inducing cytotoxic or cytostatic effects thereby decreasing the tumor growth without affecting normal cells. The fact is that the effectiveness of chemotherapy has suffered due to the lack of specificity, rapid drug metabolism and both intrinsic and acquired drug resistance as well as induction of side effects due to high dosage. This produces transient decline in quality of life of the patients suffering from cancer ${ }^{1}$.

Corresponding Author: Sunil A. Nirmal, Department of Pharmacognosy, Pravara Rural College of Pharmacy, Loni, 413736, Maharashtra, India Tel:+91 9766126772
Tamarindus indica family: Fabaceae, subfamily: Caesalpiniaceae is a tropical evergreen tree native to fertile areas throughout the Africa and Southern Asia ${ }^{2}$. It is commonly called as tamarind and widely cultivated as an ornamental tree. Due to its acidic fruits, it is used in making drinks and a popular component of many decoctions used as health remedies. Tamarindus is a monotypic genus distributed throughout many of the tropics. Different parts of the plant such as leaves, fruits and seeds have been extensively used in traditional Indian and African medicines. ${ }^{3}$. The aqueous extract of seed reduced blood sugar level and showed hypolipidemic effect by reducing $14-17 \%$ of plasma lipid, cholesterol, lipoprotein and triglycerides ${ }^{4,5}$. The seed coat extract has strong antioxidant property, used as an additive to food, in cosmetics and pharmaceutical preparations ${ }^{6}$. The seeds also inhibit the growth of urinary crystals and are used in the treatment of recurrent kidney stones ${ }^{5}$. 
All parts of $T$. indica were extensively explored for its pharmacological activities. Tamarindus indica is traditionally very important herb having many important activities like antidiabetic ${ }^{7}$, analgesic ${ }^{8}$, antioxidant, hypolipidemic ${ }^{9}$, anti-inflammatory ${ }^{10,11}$, immunomodulatory $^{12}$ and antimicrobial activity ${ }^{13,14}$. Many important phytoconstituents responsible for the various activities were isolated. This proves the therapeutic importance of the plant.

The present study aimed to evaluate anticancer potential of various extracts of leaves of $T$. indica by using various methods.

\section{MATERIALS AND METHODS}

Collection of plant material: Fresh leaves of Tamarindus indica were collected from Ahmednagar district (Maharashtra). The plant was authenticated by Dr. P.G. Diwakar, Joint Director, Botanical Survey of India, Pune and a specimen was deposited [voucher specimen number VVD-3 (Ref. No. BSI/WRC/Tech /2009/497, dated 11 Sep 2009)].

Drugs and chemicals: Cyclophosphamide $\left(\right.$ Endoxan $\left.^{\circledR}\right)$ was procured from German Remedies, Mumbai. All other chemicals such as petroleum ether $\left(60-80^{\circ} \mathrm{C}\right)$, chloroform, ethyl acetate and ethanol were of A.R. grade, procured from PCL, Pune. Saline water (Claris Life sciences Ltd., Ahmedabad) was obtained from drug store.

Preparation of extracts: Dried and coarsely powdered leaves $(150 \mathrm{~g})$ of $T$. indica were subjected for soxhlet extraction using petroleum ether, chloroform, ethyl acetate, ethanol and water as a solvent. The extracts were concentrated by vacuum distillation and dried in open air.

Preliminary phytochemical study: The preliminary phytochemical study of various extracts of $T$. indica was performed as per official methods ${ }^{15}$.

Culture and cell lines: Stock culture of Agrobacterium tumefaciens (ATCC- 33970) and HL-60 cell line culture were obtained from National Chemical Laboratory, Pune.

\section{Pharmacological screening}

Potato disc assay: Fresh potatoes were obtained from local grocery store and sterilized using $20 \%$ bleach solution. Potatoes are washed under cold running water, peeled and immersed in a $10 \%$ bleach solution for $2 \mathrm{~min}$. Test extracts $(10 \mathrm{~mL})$ were prepared in various dilutions as $0.5,0.05$ and $0.01 \mathrm{mg} \mathrm{mL}^{-1}$ in sterile water using dimethyl sulfoxide (DMSO) as suspending agent. Similarly, dilutions of cyclophosphamide of same concentration were prepared which will serve as standard solutions. A control solution containing only 5\% DMSO in sterile water was prepared.

Potatoes are rinsed with deionized water, trimmed from outside and cut into rectangular blocks $(1 \times 1 \mathrm{~cm})$ and soaked in sterile water for $20 \mathrm{~min}$. Culture plates containing $1 \mathrm{~mL}, 1.5 \%$ agar solution were prepared and potato discs were transferred in to the culture plates at the center of the wells. $400 \mu \mathrm{L}$ bacteria solution was combined with $400 \mu \mathrm{L}$ of the appropriate test, standard or control solution in test tubes using sterile micropipette. Each potato disc was inoculated with 1 drop $(50 \mu \mathrm{L})$ of the test, standard or control solution within $30 \mathrm{~min}$ after placing in wells. Plates were covered and lids were tightened using parafilm to reduce moisture loss and incubated under dry conditions at room temperature for 7-12 days. After incubation period, potato discs were stained with Lugol's solution and analyzed for staining using dissecting microscope under 10X magnification. Tumors lack starch and turned orange and normal discs stained dark blue colored ${ }^{16,17}$.

The percentage inhibition was calculated using following equation:

Percentage inhibition $=100-\frac{\text { Average No. of tumors observed in test }}{\text { Average No. of tumors observed in control }} \times 100$

Onion root tip assay: The onions are grown in a tap water for $24 \mathrm{~h}$. Sample solutions were prepared by dissolving known weight of test extracts in $0.5 \mathrm{~mL}$ of Tween 80 and diluted with distilled water $(4.5 \mathrm{~mL})$ in a series of test tube to prepare 25,50 and $100 \mathrm{mg} \mathrm{mL}^{-1}$. Likewise standard solution of cyclophosphamide were also prepared. After removal of the old roots, onion base was immersed to an extent of about $0.5 \mathrm{~cm}$ in a sample tube containing the sample solution and the immersion was continued for two days for germination. After two days, the germinated root tips were removed and placed in the sample tube containing the fixing solvent (ethanol-acetic acid, 3:1 v/v). After $24 \mathrm{~h}$, the fixing solvent was decanted and the root tips were washed with the preservative solvent $(70 \%$ alcohol) and kept in the same solvent. Similarly onion roots were also allowed to germinate in a control solution (Distilled water). Root tips were placed on a clean watch glass containing staining solution [ $1 \mathrm{~g}$ of orcein in $45 \%$ of acetic acid: 0.2 $\mathrm{N} \mathrm{HCl}(7: 1 \mathrm{v} / \mathrm{v})]$ and heated on the flame until fumes come out. It was then cooled to room temperature and placed on a micro slide; a drop of stain solution added 
and was tips were squashed by a blade. The slide was next mounted for observation under a microscope (45X). The number of dividing cells and total number of cells were counted. The percent of the number of dividing cells compared to the control and the percent inhibition of mitosis by the sample against control were calculated $^{18,19}$.

Mitotic index was calculated by following equation:

$$
\text { Mitotic index }=\frac{\text { No. of dividing cells }}{\text { Total No. of cells }} \times 100
$$

Trypan blue exclusion assay: HL-60 (Human promyelocytic leukemia) cell culture was obtained from National Center for Cell Science, Pune, India and used for the study. The cell lines were grown at $37^{\circ} \mathrm{C}$ at humidified 5\% $\mathrm{CO}_{2}$ in RPMI 1640 medium, then it was filtered using $0.45 \mu \mathrm{m}$ membrane filter. Various concentrations $\left(1-1000 \mu \mathrm{g} \mathrm{mL} \mathrm{mL}^{-1}\right.$ ) were prepared by dissolving known weight of extract in dimethyl sulphoxide (DMSO). Similar solutions containing the same concentrations of cyclophosphamide were prepared and served as standard solutions, also $10 \mathrm{~mL}$ DMSO served as control solution. Placed $0.5 \mathrm{~mL}$ of a suitable cell suspension (dilute cells in complete medium without serum to an approximate concentration of $1 \times 10^{5}$ to $2 \times 10^{5}$ cells per $\mathrm{mL}$ ) in a T-shaped flask and added $0.1 \mathrm{~mL}$ of $0.4 \%$ trypan blue stain (Merck Ltd., Mumbai), mixed thoroughly and allowed to stand for
5 min at $15-30^{\circ} \mathrm{C}$. Transferred a drop of cell suspension on heamocytometer and examined cell under a microscope and observed if non-viable are stained and viable cells excluded the stain ${ }^{20}$.

The percent cell viability determined by following equation:

Percentage cell viability $=\frac{\text { Total No. of viable cells }}{\text { Total No. of cells }} \times 100$

\section{RESULT AND DISCUSSION}

Results of the preliminary phytochemical tests showed presences of various secondary metabolites like alkaloids, steroids, saponins, flavonoids, tannins and terpenoids.

Potato disc assay: The petroleum ether extract of $T$. indica leaves showed better percentage inhibition as compared to other extracts. It showed percent (\%) inhibition $79.16 \pm 0.8 \%$ at $0.01 \mathrm{mg} \mathrm{mL}^{-1}$ while at the same concentration standard drug, cyclophosphamide showed percent (\%) inhibition $87.96 \pm 0.4 \%$ (Table 1).

Tamarindus indica is having many important phytoconstituents shown by many scientists. Based on this information, the various extracts were evaluated for their antitumor properties using potato disc bioassay. The study results showed that petroleum ether extract significantly inhibited tumor formation on potato discs which indicates it could be a potential source of

Table 1: Results of potato disc-assay of Tamarindus indica leaves extracts

\begin{tabular}{lccc}
\hline Parameters & Dilution $\left(\mathrm{mg} \mathrm{m}^{-1}\right)$ & Average No. of tumors observed & Percent inhibition (\%) \\
\hline Control & - & 72 & 00 \\
Standard drug & 0.01 & $8.667 \pm 0.3333$ & $87.96 \pm 0.4601$ \\
Petroleum ether extract & & & $85.18 \pm 0.4636$ \\
PE1 & 0.50 & $10.67 \pm 0.3333$ & $82.87 \pm 0.4632$ \\
PE2 & 0.05 & $12.33 \pm 0.3333$ & $79.16 \pm 0.8024$ \\
PE3 & 0.01 & $15.00 \pm 0.5774$ & \\
Ethanol extract & & & $76.38 \pm 1.602$ \\
ET1 & 0.50 & $17.00 \pm 1.155$ & $63.88 \pm 2.405$ \\
ET2 & 0.05 & $26.00 \pm 1.732$ & $38.89 \pm 0.7996$ \\
ET3 & 0.01 & $44.00 \pm 0.5774$ & \\
Aqueous extract & & & $77.77 \pm 0.8027$ \\
AQ1 & 0.50 & $27.33 \pm 1.453$ & $62.03 \pm 2.017$ \\
AQ2 & 0.05 & $51.33 \pm 1.202$ & $28.70 \pm 1.671$ \\
AQ3 & 0.01 & & \\
Ethyl acetate extract & & $42.67 \pm 0.8819$ & $40.73 \pm 1.226$ \\
EA1 & 0.50 & $48.33 \pm 0.3334$ & $32.87 \pm 0.4633$ \\
EA2 & 0.05 & $64.33 \pm 1.764$ & $10.49 \pm 2.481$ \\
EA3 & 0.01 & & \\
Chloroform extract & & $23.67 \pm 1.453$ & $67.12 \pm 2.02$ \\
CL1 & 0.50 & $26.33 \pm 1.202$ & $63.42 \pm 1.667$ \\
CL2 & 0.05 & $33.67 \pm 1.202$ & $53.24 \pm 1.667$ \\
CL3 & 0.01 & &
\end{tabular}

Data is expressed as mean \pm SEM, $n=6$ 
antitumor properties. Several workers conducted similar type of investigation and recommend large number of plant extracts as a potential source of anticancer agent ${ }^{21-23}$. In potato disc assay, Agrobacterium soil bacteria were used which produces tumors of roots or stem of plants. They are particularly noted for the ability to produce crown galls in plants. Galls are disorganized masses of plant cells which divide rapidly. The potato disc assay is a reliable bioassay that provides useful indication of antitumor activity. As tumors are developed, they cut off the flow of water and nutrients in the plant cell, resulting in death ${ }^{17}$.

Onion root-tip assay: Percent of the number of dividing cells and percent inhibition of mitosis by the sample against a control was calculated. Effect of various extracts on onion root tip growth in the form of mitotic index is shown in Table 2. Petroleum ether extract of $T$. indica showed least mitotic index (54.49 \pm 1.6 at $100 \mathrm{mg} \mathrm{mL}^{-1}$ concentration) as compared to other extracts. Standard drug, cyclophosphamide showed $42.56 \pm 0.2$ mitotic index at $100 \mathrm{mg} \mathrm{mL}-1$ concentration. Petroleum ether extract showed most significant and dose dependant results.

In this assay, cell cycle and dividing cells activity of the plant cells are assayed. Growth in an organism is carefully controlled by regulating the cell cycle. In plants, mitosis is nuclear division plus cytokinesis and produces two identical daughter cells during prophase, prometaphase, metaphase, anaphase and telophase ${ }^{19}$. Anti-tumor drugs that interact with microtubules and tubulin are known to block mitosis and induce cell death by apoptosis. On the other hand, cyclophosphamide alkylates DNA and proteins after it has been metabolized by cytochrome P450 to yield phosphoramide mustard and acrolein. It induces plasma membrane blebbing, DNA fragmentation and cleavage of poly (ADP-ribose) polymerase (PARP) and produces cell death by apoptosis ${ }^{24}$. The cytotoxic effect of petroleum ether extract was comparable to that of cyclophosphamide and both inhibited root growth and mitosis to a significant extent. Incubation of bulbs in different concentrations of cytotoxic agents produced a growth retarding effects.

Trypan blue exclusion assay: In this assay (HL-60 cell line) non-viable cells are stained while viable cells excluded the stain ${ }^{20}$. The activities of trypan blue exerted by all extracts are shown in Table 3 in the form of percent cell viability. Petroleum ether extract of $T$. indica showed least percent cell viability (23.43 \pm 0.1 at $1000 \mu \mathrm{g} \mathrm{mL}^{-1}$ concentration) as compared to other extracts while at the same concentration, percent cell viability of standard drug cyclophosphamide was 16.44 \pm 0.4 . Petroleum ether extract showed most significant and dose dependant results.

Table 2: Results of onion root tip assay of Tamarindus indica leaves extracts

\begin{tabular}{lccc}
\hline Concentrations $\left(\mathrm{mg} \mathrm{mL}^{-1}\right)$ & No. of dividing cell observed & Total No. of cell observed & Mitotic index (\%) Mean \pm SEM \\
\hline Control & 98.0 & 98.0 & 100 \\
Standard drug & 50.0 & 110.0 & $45.45 \pm 1.495$ \\
25 & 52.5 & 114.0 & $46.05 \pm 2.125$ \\
50 & 41.5 & 97.5 & $42.56 \pm 0.1601$ \\
100 & & & \\
Petroleum ether extract & 70.2 & 113.5 & $61.85 \pm 3.790$ \\
25 & 54.2 & 99.5 & $54.47 \pm 1.96$ \\
50 & 51.5 & 94.5 & $54.49 \pm 1.580$ \\
100 & & & $84.91 \pm 2.205$ \\
Aqueous extract & 76.0 & 89.5 & $77.88 \pm 4.220$ \\
25 & 76.5 & 99.5 & $77.31 \pm 2.445$ \\
50 & 75.0 & 97.0 & $75.74 \pm 3.685$ \\
100 & & & $71.83 \pm 3.075$ \\
Ethanol extract & 76.5 & 101.0 & $59.99 \pm 2.680$ \\
25 & 76.5 & 106.5 & \\
50 & 60.5 & 101.0 & $70.50 \pm 2.385$ \\
100 & & & $69.95 \pm 4.265$ \\
Ethyl acetate extract & 70.5 & 100.0 & $66.07 \pm 3.000$ \\
50 & 74.5 & 106.5 & $90.37 \pm 6.68$ \\
100 & 74.0 & 112.0 & $93.75 \pm 3.460$ \\
Chloroform extract & & & $91.37 \pm 3.955$ \\
50 & 84.5 & 93.5 & 96.0 \\
100 & 90.0 & 98.5 &
\end{tabular}

Data is expressed as mean \pm SEM, $\mathrm{n}=6$ 
Table 3: Results of trypan blue exclusion assay of Tamarindus indica leaves extracts

\begin{tabular}{|c|c|c|c|}
\hline Concentrations $\left(\mu \mathrm{g} \mathrm{mL}^{-1}\right)$ & Observed viable cell & Total cell count & Viability (\%) Mean \pm SEM \\
\hline Control & 89.0 & 113.0 & 78.76 \\
\hline \multicolumn{4}{|l|}{ Standard drug } \\
\hline 1000 & 18.5 & 112.5 & $16.44 \pm 0.370$ \\
\hline 100 & 21.5 & 125.0 & $17.20 \pm 0.540$ \\
\hline 10 & 26.5 & 124.0 & $21.37 \pm 0.574$ \\
\hline 1 & 22.5 & 111.5 & $20.18 \pm 0.540$ \\
\hline \multicolumn{4}{|l|}{ Petroleum ether extract } \\
\hline 1000 & 28.0 & 119.5 & $23.43 \pm 0.0953$ \\
\hline 100 & 35.5 & 106.5 & $33.33 \pm 0.5299$ \\
\hline 10 & 47.5 & 105.0 & $45.23 \pm 0.0432$ \\
\hline 1 & 58.0 & 97.0 & $59.79 \pm 1.0300$ \\
\hline \multicolumn{4}{|l|}{ Ethanol extract } \\
\hline 1000 & 25.5 & 111.0 & $22.97 \pm 0.6550$ \\
\hline 100 & 44.0 & 106.5 & $41.31 \pm 1.5200$ \\
\hline 10 & 55.5 & 98.5 & $56.34 \pm 0.2647$ \\
\hline 1 & 60.0 & 89.5 & $67.04 \pm 0.3746$ \\
\hline \multicolumn{4}{|l|}{ Aqueous extract } \\
\hline 1000 & 33.5 & 102.0 & $32.84 \pm 0.8149$ \\
\hline 100 & 47.5 & 96.5 & $49.22 \pm 0.7900$ \\
\hline 10 & 60.0 & 94.0 & $63.82 \pm 0.3855$ \\
\hline 1 & 62.5 & 88.0 & $71.02 \pm 3.1400$ \\
\hline \multicolumn{4}{|l|}{ Ethyl acetate extract } \\
\hline 1000 & 33.5 & 117.0 & $28.63 \pm 0.4250$ \\
\hline 100 & 47.0 & 103.0 & $45.63 \pm 3.8850$ \\
\hline 10 & 48.0 & 100.0 & $48.00 \pm 0.4850$ \\
\hline 1 & 61.0 & 93.0 & $65.59 \pm 5.7400$ \\
\hline \multicolumn{4}{|l|}{ Chloroform extract } \\
\hline 1000 & 37.0 & 93.5 & $39.57 \pm 2.1250$ \\
\hline 100 & 50.5 & 102.0 & $49.50 \pm 0.4952$ \\
\hline 10 & 53.5 & 96.5 & $55.44 \pm 0.2356$ \\
\hline 1 & 61.0 & 87.0 & $70.11 \pm 4.0450$ \\
\hline
\end{tabular}

Data is expressed as mean \pm SEM, $\mathrm{n}=6$

Trypan blue is a large anionic dye that belongs to the group of azo dyes. It is traditionally used as a component of polychromatic stains. Its reactivity is based on the negatively charged chromophore which does not interact with the cell unless the membrane is damaged. The cytotoxicity of petroleum ether extract on HL-60 cell line was further confirmed by trypan blue dye exclusion assay. The ability of the cells to survive a toxic insult has been the basis of most cytotoxicity assays. This assay was based on the assumption that the dead cells will take the dye and viable cells won' $t^{25}$.

Petroleum ether extracts showed most significant and dose dependant activities in all three methods studied for anti-tumor activity. The petroleum ether extract might inhibit the initiation and growth of tumors which can be seen by results obtained in potato disc assay. Also extract might inhibit mitosis at different phases which results in inhibition of cell growth and cell toxicity which is observed in onion root tip assay. Least cell viability is observed in trypan blue assay which signifies cell toxicity of the extract.

It can be concluded that petroleum ether extract of $T$. indica leaves have potency to prevent or manage cancer cell growth.

\section{REFERENCES}

1. Amini, A., L.A. Byers, J.W. Welsh and R.U. Komaki, 2014. Progress in the management of limited-stage small cell lung cancer. Cancer, 120: 790-798.

2. Kirtikar, K.R. and B.D. Basu, 1956. Indian Medicinal Plants. 2nd Edn., International Book Distributors, Deharadun, India, pp: 887-891.

3. Gunasena, H.P.M. and A. Hughes, 2000. Tamarind (Tamarindus indica L.). International Center for Underutilized Crops, Southampton, UK., pp: 1-169.

4. Yamatoya, K., M. Shirakawa, K. Kuwano, J. Suzuki and T. Mitamura, 1996. Effects of hydrolyzed xyloglucan on lipid metabolism in rats. Food Hyd., 10: 369-372.

5. Dhasade, V.V., S.A. Nirmal, N.S. Dighe and S.R. Pattan, 2009. An overview of Tamarindus indica Linn.: Chemistry and pharmacological profile. Pharmacologyonline, 3: 809-820.

6. Yamatoya, K., M. Shirakawa and O. Babar, 1998. Effects of Xyloglucan on lipid metabolism. Food Hyd., 2: 405-410. 
7. Maiti, R., D. Jana, U.K. Das and D. Ghosh, 2004. Antidiabetic effect of aqueous extract of seed of Tamarindus indica in streptozotocin-induced diabetic rats. J. Ethnopharmacol., 92: 85-91.

8. Dighe, N.S., S.R. Pattan, S.A. Nirmal, R.S. Kalkotwar, V.M. Gaware and M.B. Hole, 2009. Analgesic activity of Tamarindus indica. Res. J. Pharmacog. Phytochem., 1: 69-71.

9. Martinello, F., S.M. Soares, J.J. Franco, A.C. Santos and A. Sugohara et al., 2006. Hypolipemic and antioxidant activities from Tamarindus indica L. pulp fruit extract in hypercholesterolemic hamsters. Food Chem. Toxicol., 44: 810-818.

10. Singh, S., S. Bani, G.B. Singh, B.D. Gupta, S.K. Banerjee and B. Singh, 1997. Anti-inflammatory activity of lupeol. Fitoterapia, 68: 9-16.

11. Rimbau, V., C. Cerdan, R. Vila and J. Iglesias, 1992. Anti-inflammatory activity of some extracts from plants used in the traditional medicine of north-African countries (II). Phytother. Res., 13: $128-132$.

12. Sreelekha, T.T., T. Vijayakumar and R. Ankanthil, 1993. Immunomodulatory effect of a polysaccharide from Tamarind indica seed. Anticancer Drugs, 4: 209-212.

13. Doughari, J.H., 2006. Antimicrobial activity of Tamarindus indica Linn. Trop. J. Pharm. Res., 5: 597-603.

14. Ross, S.A., S.E. Megalla, D.W. Dishay and A.H. Awad, 1980. Studies for determining antibiotic substances in some Egyptian plants. Part I. Screening for antimicrobial activity. Fitoterapia, 51: 303-308.

15. Khandelwal, K.R., 2005. Practical Pharmacognosy Technique and Experiments. 23rd Edn., Nirali Prakashan, Pune, India, pp: 15-29, 149-156.

16. Ferrigni, N.R., J.E. Putnam, B. Anderson, L.B. Jacobsen and D.E. Nichols et al., 1982. Modification and evaluation of the potato disc assay and antitumor screening of euphorbiaceae seeds. J. Nat. Prod., 45: 679-686.
17. Coker, P.S., J. Radecke, C. Guy and N.D. Camper, 2003. Potato disc tumor induction assay: A multiple mode of drug action assay. Phytomedicine, 10: $133-138$.

18. Williams, G.O. and L.E. Omoh, 1996. Mitotic effects of the aqueous leaf extract of cymbopogon citratus in Allium cepa root tips. Cytobios, 87: 161-168.

19. Lokanatha Rai, K.M., Y.B. Basavaraju and B. Sadashivamurthy, 2007. Biological assay and antimitotic activity of novel analogues of $\beta$-apopicropodophyllin. Indian J. Pharmaceut. Sci., 69: 116-118.

20. Freshney, R., 1987. Culture of Animal Cells: A Manual of Basic Technique. Wiley Eastern Ltd., New York, USA., pp: 20-25.

21. Turker, A.U. and N.D. Camper, 2002. Biological activity of common mullein, a medicinal plant. J. Ethopharmacol., 82: 117-125.

22. Prado, S.R., V. Cechinel-Filho, F. Campos-Buzzi, R. Correa, S.M. Cadena and M.B. de Oliveira, 2004. Biological evaluation of some selected cyclic imides: Mitochondrial effects and in vitro cytotoxicity. Z. Naturforsch C, 59: 663-672.

23. Hussain, A., M. Zia and B. Mirza, 2007. Cytotoxic and antitumor potential of Fagonia cretica L. Turk. J. Biol., 31: 19-24.

24. Sehgal, R., S. Roy and V.L. Kumar, 2006. Evaluation of cytotoxic potential of latex of Calotropis procera and Podophyllotoxin in Allium cepa root model. Biocell, 30: 9-13.

25. Unnikrishnan, M.C. and R. Kuttan, 1988. Cytotoxicity of extracts of spices to cultured cells. Nutr. Cancer, 11: 251-257. 